\title{
A diagnostic model for M.S.W. landfill operation and the protection of ecosystems with a spatial multiple criteria analysis - Zakynthos Island, Greece
}

\author{
T. Koliopoulos ${ }^{1} \&$ G. Koliopoulou ${ }^{2}$ \\ ${ }^{1}$ Centre of Environmental Management Research, \\ University of Strathclyde, Environmental Consultancy, Greece \\ ${ }^{2}$ Department of Experimental Physiology, Medical School, \\ University of Athens, Greece
}

\begin{abstract}
Sanitary landfills remain an attractive disposal route for municipal solid waste, because it is more economical than alternative solutions. The produced landfill emissions by waste biodegradation could be exploited after treatment as renewable resources. In this paper the experimental design of Mid Auchencarroch landfill is taken into account, which is a UK Environment Agency and industry funded research facility. The relative magnitudes of pollution load in time by landfill gas and leachate emissions are considered, making useful conclusions for the operation of future sustainable integrated waste management systems and associated regional sustainable development protecting ecosystems and public health.

Keywords: landfill design, waste emissions' topography, spatial analysis, lining of monitoring systems, integrated waste management systems, sustainable development, public health.
\end{abstract}

\section{Introduction}

A municipal integrated solid waste system facilitates the operation of one or more operational techniques and technologies of solid waste management systems such as landfilling, incineration, compost production, recycling, leachates treatment, waste vehicles transport etc. $[2,5,6,13,20]$. Sanitary landfills 
remain an attractive disposal route for municipal solid waste, because, it is more economical than alternative solutions. It is accepted that the landfill biodegradation processes are complex, including many factors that control the progression of the waste mass to final stage quality [6-9]. The landfill gas and leachate generation is an inevitable result of the solid waste biodegradation in landfills and their study is necessary for future efficient designs, controlling air, soil and groundwater pollution $[3,7,8,20]$. This paper presents an analysis of exploitation of produced landfill emissions for regional development using proper technologies. The use of controlled batch anaerobic bioreactors accelerates waste biodegradation in short periods, avoiding any associated environmental risks due to landfill emissions [1,4-8]. Any uncontrolled dumps have to close so as to avoid any threats to the public health and to protect the ecosystems and the environmental resources.

Large sanitary landfills are preferred because these provide better opportunities for potential hazard control and an increasing potential for resource recovery. Efficiently managed sustainable landfill sites can generate considerable volumes of methane gas $\left(\mathrm{CH}_{4}\right)$, which can be exploited by proper landfill gas recovery installations to produce electricity or natural gas. The produced landfill gas could be exploited for energy recovery, for greenhouse heating, for biofuel use and for energy supply at several anthropogenic activities of land uses. Treated leachates, after the use of proper technologies should be used for water supply in irrigations networks and other related regional development public works, in order to minimise the use of raw resources.

\section{The case study: Zakynthos Island landfill's boundaries determination}

This paper presents the decision making for efficient lining of landfill boundaries and its final location. However, efficient waste management techniques should be followed for satisfactory waste biodegradation in anaerobic landfill bioreactors like those which have been followed on Mid Auchencarroch experimental landfill project, which is located outside from Glasgow city, in Scotland [6-9].

The experimental landfill Mid Auchencarroch is a field scale facility, constructed in order to assess a number of techniques that promote sustainable landfill. Mid Auchencarroch experimental landfill is an Environment Agency, DTI and industry funded research facility. Mid Auchencarroch (MACH) experimental landfill has been capped since 1995 [6-9]. Effective diagnostic models should be used not only to evaluate current landfill projects but also to propose efficient solutions and give confrontations to associated environmental problems from landfill emissions based on any available experimental data from the literature.

In this paper is examining as case study the determination of landfill location and its boundaries' lining for the protection of any important environmental resources and ecosystems on Zakynthos Greek Ionian Sea Island in west Greece (Fig.1). It has been selected this island as is living on it the loggerhead turtle 
(Caretta Caretta), which is listed as an endangered species within the EU boundaries. It is included in Annex II (priority species) and Annex IV of the Habitats Directive (92/43/EEC). The beaches of Zakynthos are hosting the last and most important concentration of loggerhead turtle, Caretta Caretta. Since its major nesting areas in Greece have been identified and are under various protective and management schemes (all included in the national list of proposed Natura 2000 sites), mortality at sea emerges as a high priority, which if not addressed might also undermine conservation efforts at nesting areas. Several environmental activities are taking place so as to protect Carreta Caretta. The latter activities are supported by several Environmental Organisations (Archelon, wwf etc.) focused on the reduction of losses of Caretta Caretta at sea, and the protection of its eggs.

Moreover, on Zakynthos island there is the Mediterranean monk seal (Monachus monachus), for which the incidental entanglement in fishing gear is considered a major threat contributing to the overall decline of the species. Gulf Lagana is a protected area for the Caretta Caretta turtle. The southern gulf of Zakynthos and the Strofades are considered as protected areas where usually are visited by migrating birds, wild swans, swallows, kingfishers, and sea gulls $[10,19]$.

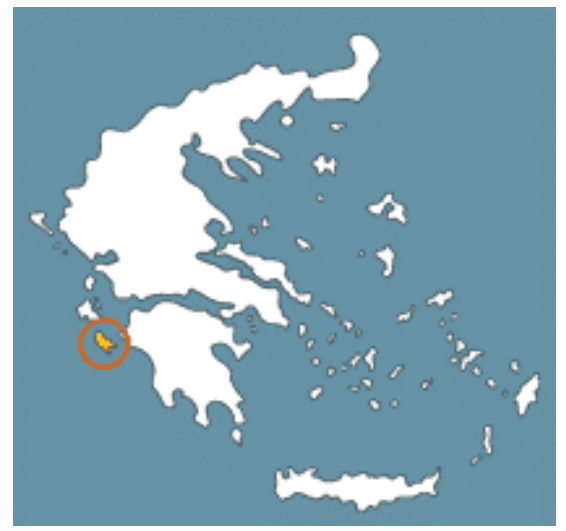

Figure 1: $\quad$ Map of Greece and Zakynthos Island location in West Greece.

Zakynthos is the capital and port of the island, located at the foot of Bochali hill. Zakynthos is known as D. Solomos's and A. Kalvos's island, who were lived on the island in past times, and they are among the great national poets and writers of Greece $[14,19]$. On the coasts, there are several fabulous tourist resorts with a wide variety of accommodations for tourists. On the island there are six municipalities which are the followings: Alykon, Arkadion, Artemision, Elation, Laganas and Zakynthion, Alikon, Arkadiou, Artemision, Lagana and Zakinthou. The municipality of Zakynthion covers the south east area of Zante and is the most populated of all the rest municipalities, with a population of over 14,000 inhabitants compared to about 4,000 inhabitants in the rest municipalities. The total population on the island is approximately 38600 inhabitants. The Prefecture 
of Zakynthos is a non-profit Greek Governmental Organisation that is involved in the running of these areas to advise and assist with administration, citizenship, economic development and tourism in collaboration with the Municipalities' Association of Zakynthos [15,19].

\section{Spatial analysis}

On Zakynthos Island there is a Marine Park, which is a protected area and is located along the southern coast from the promontory of Marathia's Cape to the beach of Gerakas, including the outback of the beaches of Limni Kerì, Laganas and Kalamaki and the Strofades, two small islands 50 nautical miles southern of Zakynthos. This area presents the main characteristics of the Mediterranean Ecosystem, with sandy beaches, emerging rocks and sandy dunes, whereas in the outback there are thick pinewoods, fertile areas for the agriculture and the Mediterranean landscape with spontaneous vegetation [10,16,17].

The mountainous zone of the island covers $40 \%$ of its total surface, which consists of villages with different characteristics. The distribution of road network on the island is different from west to east and from north to south (Fig.2). To the north there are the towns of Volimes and Katastari, which are the capitals of the Municipalities Elation and Alikon respectively. To the west there are picturesque villages Agios Leon and Kiliomeno. To the south there are Agalas, Keri and other villages with many elements of traditional architecture, which retain the traditions of the island and are visited by many tourists during vacations $[10,19]$.

However, based on the experimental elements of MACH project, which is a test bed for sequential batch landfill bioreactors and controls an enhanced degradation system there has been developed a simulation numerical model of landfill biodegradation stages and its associated emissions (i.e. simulation of gas risk, SimGasRisk) [8,9]. MACH project showed that is possible to control and enhance landfill gas, heat generation and flush potential leachate and other pollutants from the waste mass, by manipulating the whole process of landfill. Landfill concept in small depths can be used as an efficient sustainable sequential batch bioreactor [5-9].

A comprehensive spatial analysis model should be developed following the next steps. Based on SimGasRisk's simulation numerical results for a given waste composition can be defined the advection velocity of probable landfill gas migration so as to determine useful spatial thresholds next to landfill boundaries, protecting any nearby ecosystems and environmental receptors from landfill emissions. The final lining of a proposed landfill location should take into account the latter fact protecting any nearby ecosystems; public health and anthropogenic properties. Moreover, based on the magnitudes of local average wind velocities and utilising SimGasRisk's results could be determined threshold areas where there is influence on them by landfill gases emissions (i.e. carbon dioxide, methane etc.) so as to take the relative measures in time for the nearby land uses and their proper management $[7,10,11,12,20]$. 


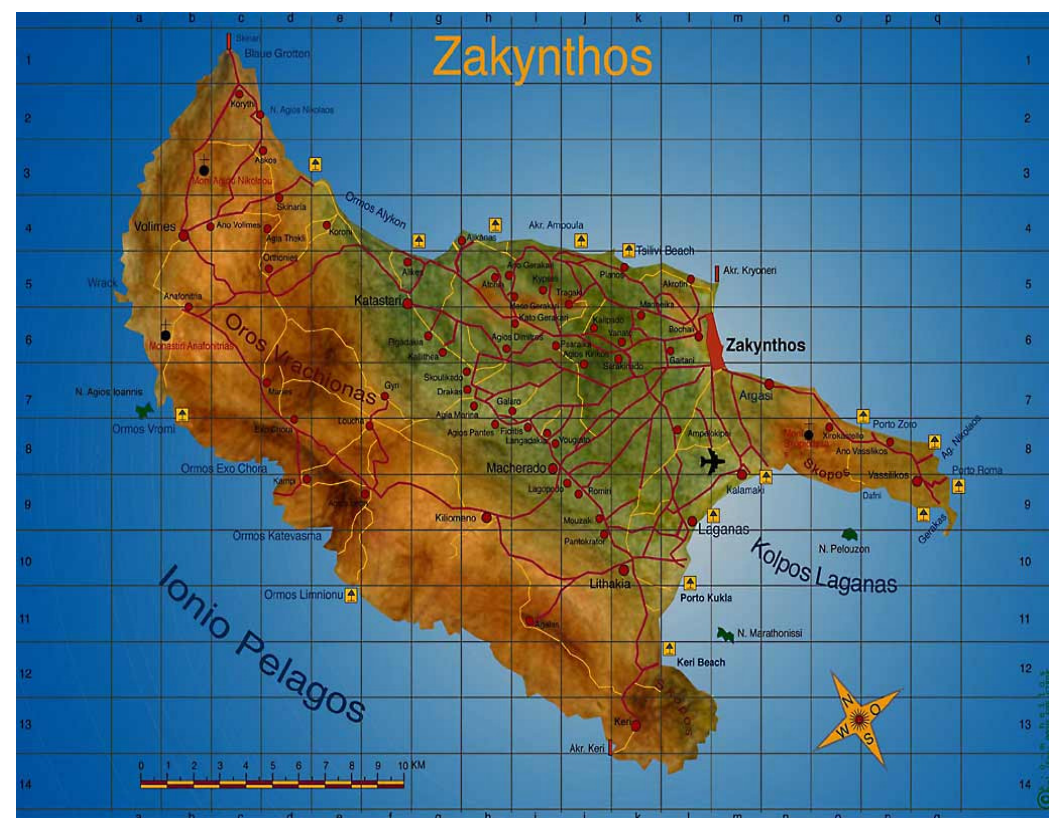

Figure 2: $\quad$ Map of Zakynthos Island.

The current operating landfill of Zakynthos is located next to the borders of Lagana and Zakinthion Municipalities at south-east part of island. The latter existing location provokes with its emissions several problems to the nearby protective area of Laganas Gulf. However, there have been proposed three main areas for a new landfill location on the island, according to the Municipalities' Association of Zakynthos. The latter proposed locations are the three followings: i) next to Agalas village, which is located next to the borders between the Municipalities Artemision and Lagana; ii) south at Skopos mountain; iii) next to the borders between the Municipalities Elation and Alikon or Municipalities Elation and Artemision [15,19].

The first examining location could be presented as a safe decision, due to the fact that the existence of the eastern mountainous area next to Agalas village protects all the main ecosystems' population and inhabitants, which are located to the east of the island. This selection will avoid any annoying odours and any associated risks from landfill emissions to the nearby ecosystems and human populations. Relative measures should be taken during the final lining of the landfill location for the protection of any surrounded rivers or ground waters. The lining of a dense monitoring system in space and frequent samples of landfill emissions in time should take place next to landfill boundaries.

Moreover, the second choice could be characterised safe if it assures that the selection of the final landfill location should not provoke any risks and hazards to the ecosystem of Laganas gulf. It should be away from the ecosystem area and should be constructed on the western side of the island. However, the third examining scenario of landfill location is not too favourable in comparison to the 
previous two ones. It includes the risk of probable landfill gases dispersion to the nearby villages to the east and south part of the island, provoking several probable environmental impacts to the surrounded ecosystems and human populations.

The selection of landfill site location for the final solid waste disposal depends on a number of fundamental parameters which must be investigated in depth securing an acceptable situation to the surroundings of the site during its operation. The following parameters should be identified in detail in collaboration with the Local Authorities, during the selection of the final landfill site location:

- Several socioeconomic and other parameters, which include the necessary landfill surface in relation to the served population; the solid waste which produced per capita; the solid waste composition and the selected waste disposal method;

- Topographical parameters including topographical data of the site for its lining during its operational life cycle;

- Environmental parameters assessing impacts and respective confrontation (i.e. lining landfill access roads with busy traffic which should not be closed to residences; noise protection taking into account local wind characteristics and the location either of neighbouring ecosystems or of the existence of natural resources exploitation (i.e. agro-tourism's units, agricultural production units, irrigation works' units etc.);

- Hydrological parameters covering the regional water circulation from which one part flows to the landfill surface provoking operational problems;

- Climatological parameters. Wind, rain and temperature directly affect sanitary landfill design, operation and maintenance;

- Geological parameters. The permeability of the substratum should be investigated. The minimum distance between the bottom of the site and the first ground aquifer is a very important parameter to be determined.

- Exploitation parameters including good access to the nearby road network, water supply, electricity, telephone, sewage facilities, fire protection equipment and other facilities.

Therefore, the suitable criteria $\mathrm{C}$ could be outlined, in accordance with the analysis of the above parameters so as to select the optimum of landfill location minimising any threats to the nearby ecosystems. The established criteria that refer to the satisfaction of the examining parameters can be represented as $\mathrm{C}_{1}$, $\mathrm{C}_{2}, \mathrm{C}_{3}, \ldots, \mathrm{C}_{\mathrm{n}}$. Their values can be estimated through experience and could be based on the bibliography. The influence of the selected criteria is estimated through the insertion of weight coefficients: $a_{1}, a_{2}, a_{3}, \ldots, a_{n}$ which can be classified as high, middle or low. The quality of the investigated site can be estimated by equation (1), when are taken into account the products of the examining criteria and the weight coefficients respectively:

$$
\mathrm{Q}=\sum_{i=1}^{n} \mathrm{a}_{\mathrm{i}} \mathrm{c}_{\mathrm{i}}
$$

where $C_{i}$ is the value of class $i$ criterion and $a_{i}$ its weight coefficient. 
Below is calculated the mathematical expectation of the population of Zakynthos Island in 2031. The calculation of the population $P_{n}$ after $n$ years, there will be according to the following demographic formula (2):

$$
\mathrm{P}_{\mathrm{n}}=\mathrm{P}_{\mathrm{o}} *(1+\mathrm{t})^{\mathrm{n}}
$$

where

$\mathrm{P}_{0}$ is the approximate population of Zakynthos island in 2001, $\mathrm{P}_{0}=38,600$ inhabitants. An increase $10 \%$ of population is taken for safety reasons covering additional necessities during holiday's peak season. Hence, $\mathrm{P}_{0}=42,460$ inhabitants,

$\mathrm{t}$ is the annual increase of population growth, is taken $2.5 \%$, $\mathrm{n}=30$ years life cycle operation of landfill from 2001 to 2031 .

According to equation (2), it yields:

$$
\mathrm{P}_{2031}=42,460 *(1.025)^{30}=42,460 * 2.098=89,081 \text { inhabitants }
$$

Taking that the production of waste is $0,8 \mathrm{~kg}$ per inhabitant and per day for the above examining inhabitants' population and applying SimGasRisk simulation model, could be calculated probable air pollutants' emissions from landfill boundaries to the nearby areas taking into account the following equations. The concentration $\mathrm{C}$ of an examining air pollutant along the central line of axis $\mathrm{x}$ from landfill boundary, taking the source of air pollutant on a height $\mathrm{H}$ from the ground surface could be calculated by the following equation (4), for the examining comprehensive spatial analysis diagnostic model $[7,9,11,12]$.

$$
C(x, 0,0, H)=\frac{Q}{\pi u \sigma_{y} \sigma_{z}} \exp \left(-\frac{1}{2} \frac{H^{2}}{\sigma_{z}^{2}}\right)
$$

$\sigma_{\mathrm{y}}, \sigma_{\mathrm{z}}$ dispersion coefficients dependent on $\mathrm{x}$, and their relation is presented below. Also the concentration $\mathrm{C}$ of an examining air pollutant along the cross section to the central line at location $(\mathrm{x}, \mathrm{y})$ from landfill boundary, could be calculated by the following equation (5), for the examining comprehensive spatial analysis diagnostic model, taking the source of air pollutant on a height difference $\mathrm{H}$ related to the location $(\mathrm{x}, \mathrm{y})$ of the receptor $[7,9,11,12]$.

$$
C(x, y, 0, H)=\left[\exp \left(-\frac{1}{2} \frac{y^{2}}{\sigma_{y}^{2}}\right)\right] \frac{Q}{\pi u \sigma_{y} \sigma_{z}} \exp \left(-\frac{1}{2} \frac{H^{2}}{\sigma_{z}^{2}}\right)
$$

where

Q gas emissions from the source $(\mathrm{Kg} / \mathrm{sec})$

C air pollutant concentration at location $\chi, \mathrm{y}$ from a height $\mathrm{H}\left(\mathrm{Kg} / \mathrm{m}^{3}\right)$

$\mathrm{u} \quad$ wind velocity $(\mathrm{m} / \mathrm{sec})$ 
$\mathrm{x} \quad$ is defined by the respective $\mathrm{x}$ distance on $\mathrm{x}$ axis, from the source of air pollutant to a nearby civic, industrial or agricultural land use receptor area, based on the particular spatial data of the examining proposed landfill sites' areas. The selected $\mathrm{x}$ distance is applied on the following graphs (Fig. 3) so as to determine the respective dispersion coefficients in relation to atmospheric stability conditions A, B, C, D, E or F.

$\mathrm{y} \quad$ is defined as the transverse distance to the above selected $\mathrm{x}$ location for which is calculated the air pollutant concentration. The y distance is based on particular map data of nearby land uses next to the examining proposed landfill sites' areas. The selected y distance is applied on the graph of $\sigma_{z}$ dispersion coefficient versus distance (Fig. 3) so as to determine the respective value of dispersion $\sigma_{z}$ coefficient in relation to atmospheric stability conditions A, B, C, D, E or F.

$\sigma_{\mathrm{y}}, \sigma_{\mathrm{z}}$ dispersion coefficients dependent on $\mathrm{x}$, they are calculated based on Fig.3 graphs or by the corresponding least squares fitting curves based on Fig.3 data [15], which are presented below:

$\sigma_{\mathrm{y}}$, for A atmospheric stability condition

$$
\sigma_{\mathrm{y}}=-310^{-16} \mathrm{x}^{4}+510^{-11} \mathrm{x}^{3}-410^{-06} \mathrm{x}^{2}+0.2031 \mathrm{x}+10.581, \mathrm{R}^{2}=0.9997 ;
$$

$\sigma_{\mathrm{y}}$, for $\mathrm{B}$ atmospheric stability condition

$$
\sigma_{\mathrm{y}}=210^{-16} \mathrm{x}^{4}-210^{-11} \mathrm{x}^{3}+310^{-08} \mathrm{x}^{2}+0.1133 \mathrm{x}+36.938, \mathrm{R}^{2}=0.9973 ;
$$

$\sigma_{\mathrm{y}}$, for $\mathrm{C}$ atmospheric stability condition

$$
\sigma_{\mathrm{y}}=-810^{-17} \mathrm{x}^{4}+110^{-11} \mathrm{x}^{3}-110^{-06} \mathrm{x}^{2}+0.0922 \mathrm{x}+12.849, \mathrm{R}^{2}=0.9984 ;
$$

$\sigma_{\mathrm{y}}$, for $\mathrm{D}$ atmospheric stability condition

$$
\sigma_{\mathrm{y}}=610^{-17} \mathrm{x}^{4}-110^{-11} \mathrm{x}^{3}+210^{-07} \mathrm{x}^{2}+0.0581 \mathrm{x}+17.218, \mathrm{R}^{2}=0.9986
$$

$\sigma_{\mathrm{y}}$, for $\mathrm{E}$ atmospheric stability condition

$$
\sigma_{\mathrm{y}}=-210^{-17} \mathrm{x}^{4}+610^{-12} \mathrm{x}^{3}-510^{-07} \mathrm{x}^{2}+0.0472 \mathrm{x}+9.9535, \mathrm{R}^{2}=0.9979 ;
$$

$\sigma_{\mathrm{y}}$, for $\mathrm{F}$ atmospheric stability condition

$$
\sigma_{y}=-410^{-17} x^{4}+910^{-12} x^{3}-610^{-07} x^{2}+0.0333 x+3.8686, R^{2}=0.999
$$

$\sigma_{\mathrm{z}}$, for $\mathrm{A}$ atmospheric stability condition

$$
\sigma_{\mathrm{z}}=-610^{-11} \mathrm{x}^{4}+310^{-07} \mathrm{x}^{3}+110^{-05} \mathrm{x}^{2}+0.1812 \mathrm{x}-5.1457, \mathrm{R}^{2}=0.9999 ;
$$

$\sigma_{\mathrm{z}}$, for $\mathrm{B}$ atmospheric stability condition

$$
\sigma_{z}=110^{-13} x^{4}-310^{-09} x^{3}+210^{-05} x^{2}+0.0899 x-1.7552, R^{2}=0.9988 ;
$$

$\sigma_{\mathrm{z}}$, for $\mathrm{C}$ atmospheric stability condition

$$
\sigma_{z}=-110^{-15} x^{4}+110^{-10} x^{3}-310^{-06} x^{2}+0.0742 x-7.5725, R^{2}=0.9982 ;
$$

$\sigma_{\mathrm{z}}$, for $\mathrm{D}$ atmospheric stability condition

$$
\sigma_{z}=-310^{-17} x^{4}+710^{-12} x^{3}-510^{-07} x^{2}+0,0183 x+12.887, R^{2}=0.9965
$$

$\sigma_{\mathrm{z}}$, for $\mathrm{E}$ atmospheric stability condition

$$
\sigma_{z}=-110^{-17} x^{4}+310^{-12} x^{3}-310^{-07} x^{2}+0.0093 x+11.559, R^{2}=0.9899 ;
$$

$\sigma_{\mathrm{z}}$, for $\mathrm{F}$ atmospheric stability condition

$$
\sigma_{\mathrm{z}}=-110^{-17} \mathrm{x}^{4}+210^{-12} \mathrm{x}^{3}-210^{-07} \mathrm{x}^{2}+0.0062 \mathrm{x}+6.3454, \mathrm{R}^{2}=0.9868 .
$$
$\mathrm{A}, \mathrm{B}, \mathrm{C}$
D, E, F

atmospheric stability categories that are selected based on meteorological conditions which are described in Table 1.

where $\mathrm{A}$ is high unstable; $\mathrm{B}$ is medium unstable; $\mathrm{C}$ is low unstable; D neutral; $\mathrm{E}$ low stable and F very stable type of atmospheric stability. Source: [15]. 

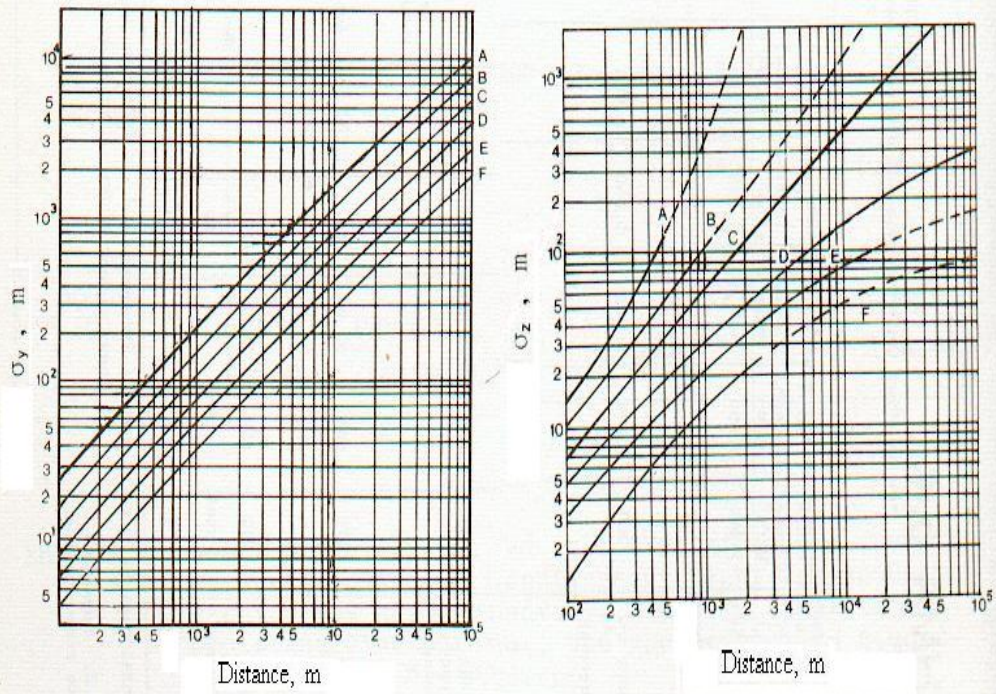

Figure 3: $\sigma_{\mathrm{y}}, \sigma_{\mathrm{z}}$ dispersion coefficients dependent on $\mathrm{x}$ distance between the source of air pollutant and the receptor location. Source: [15].

Table 1: $\quad$ Categories A, B, C, D, E, F of atmospheric stability.

\begin{tabular}{|c|c|c|c|c|c|}
\hline $\begin{array}{c}\text { Wind } \\
\text { velocity } \\
\text { at 10m } \\
\text { height } \\
\text { from } \\
\text { G.L. } \\
\text { (m/s) }\end{array}$ & $\begin{array}{c}\text { High } \\
\text { solar } \\
\text { radiation } \\
\text { during } \\
\text { day }\end{array}$ & $\begin{array}{c}\text { Middle } \\
\text { solar } \\
\text { radiation } \\
\text { during } \\
\text { day }\end{array}$ & $\begin{array}{c}\text { Low solar } \\
\text { radiation } \\
\text { during } \\
\text { day }\end{array}$ & $\begin{array}{c}\text { Cloudiness } \\
\text { of sky, n, } \\
\text { during } \\
\text { night, } \\
\text { covered } \\
\text { (n } \geq \mathbf{4} / \mathbf{8})\end{array}$ & $\begin{array}{c}\text { Cloudiness } \\
\text { of sky, n, } \\
\text { during } \\
\text { night, } \\
\text { clear } \\
\text { (n } \leq \mathbf{3 / 8})\end{array}$ \\
\hline$>2$ & A & A-B & B & E & F \\
\hline $2-3$ & A-B & B & C & E & F \\
\hline $3-5$ & B & B-C & C & D & E \\
\hline $5-6$ & C & C-D & D & D & D \\
\hline$>6$ & C & D & D & D & D \\
\hline
\end{tabular}

An application of equations (4) and (5) is given below. A CO emission is examined for $\mathrm{x}=600 \mathrm{~m}, \mathrm{y}=60 \mathrm{~m}$ distances from landfill boundary to a nearby industrial land use area with $\mathrm{CO} 6615.56 \mu \mathrm{g} / \mathrm{s}$ air pollutant emission and applying equations (4) and (5) for $\mathrm{D}$ atmospheric stability category, $\mathrm{H}=15 \mathrm{~m}$ the height difference from the source of air-pollutant to the examining location and wind velocity $5.5 \mathrm{~m} / \mathrm{sec}$ at $10 \mathrm{~m}$ height above (G.L.), it yields $0.307 \mu \mathrm{g} / \mathrm{m}^{3}$ at $\mathrm{x}=$ $600 \mathrm{~m}$ distance from the source on $\mathrm{x}$ axis and $0.126 \mu \mathrm{g} / \mathrm{m}^{3}$ at $\mathrm{y}=60 \mathrm{~m}$ transverse distance to $\mathrm{x}$ axis. The results which were found above both are under the health and safety limits for a human working on that location avoiding any 
epidemiologic public health effect (limit $<10 \mathrm{mg} / \mathrm{m}^{3}$ in 8 -hour base) $[4,11,14$, 15]. The latter calculated emissions should be evaluated with any other combined produced $\mathrm{CO}$ emissions from any surrounded anthropogenic activities, taking the relative measures so as to minimise any associated environmental pollution to the ecosystems.

Thresholds maps of air pollutants, for the examining case study, could be determined based on equations (4) and (5) evaluating the relative available spatial data; respective probable environmental impacts and the final lining of landfill boundaries on the ground surface and optimum lining of surrounded traffic and transport systems so as to protect the surrounded ecosystems and civic, agricultural zones. However, there could be lined a dense monitoring network on the particular examining landfill emissions' threshold contours taking frequent samples in time and evaluating the measurements for additional risk assessments and probable lining of bioremediation works. Moreover, an optimum solution could be given based on detailed socioeconomic data, and annual population trends, utilising GIS, GPS database system analysis, operational research or other digital geographical tools for the lining of safe waste vehicles' routes for waste shipment from the source to landfill site in order to minimise fuel consumption and air pollutants emissions, protecting the nearby ecosystems $[13,17,18]$.

\section{Results and discussion}

The comprehensive simulation numerical models, which have been validated and they are robust, based on field measurements of experimental sites like Mid Auchencarroch one and on the bibliographical sources, should be used as diagnostic tools as it was described above. The uses of dynamic models, like SimGasRisk, are necessary so as to model and analyse biomass biodegradation for efficient bioreactor designs and control of particular produced emissions. During the lining of landfill boundaries should be taken into account the surrounded existing areas of ecosystems, land uses and other anthropogenic activities that are taking place there. The associated risk assessment spatial analysis could give a solution to the latter problem analysing the particular factors and parameters that affect on it. Hence the thresholds of migrated landfill gas could be calculated by the solution of the diffusion-advection problem, which is described by the following equation (6).

$$
R \frac{\partial C}{\partial t}=D \frac{\partial^{2} C}{\partial x^{2}}-V \frac{\partial C}{\partial x}
$$

where

$C \quad$ gas concentration by volume

$x \quad$ the distance along the migration pathway (m)

$t \quad$ is time (s)

$D$ the diffusion coefficient $\left(\mathrm{m}^{2} / \mathrm{s}\right)$

$V \quad$ velocity $(\mathrm{m} / \mathrm{s})$

$\mathrm{R}$ the retardation factor 
Moreover, an estimation has been made for the calculation of lateral distance of biogas migration and probable explosions next to landfill boundaries, assuming that the threshold of 0.1 biogas concentration by volume will take place in 6 years since gas was migrated from landfill boundaries and taking constant the values of the advection velocity and diffusion coefficient. The retardation factor describes the interaction of ground with biogas and according to the bibliography, the retardation factor $\mathrm{R}$ equals to 1 , in the case of landfill gas flow in the soil porous media, for other cases several experiments should be made [19]. However, the biogas diffusion coefficient D in the porous medium is related to the porosity $\Phi$ of the porous medium and to the gas diffusion of the biogas in air Do $=1.710^{-5}\left(\mathrm{~m}^{2} / \mathrm{s}\right)$, by the following equation (7) [21]:

$$
\frac{D}{D_{o}}=\Phi^{1.33}
$$

Hence, according to the above, the solution of equation (6) yields the investigated distance, which is $33 \mathrm{~m}$, combining equations (6) and (7) for the next data $\mathrm{V}=1.510^{-7}(\mathrm{~m} / \mathrm{s}), \mathrm{R}=1$ and $\mathrm{D}=310^{-6}\left(\mathrm{~m}^{2} / \mathrm{s}\right)$ for $\Phi=0.3$ porosity of soil, $\mathrm{D}_{\mathrm{o}}=1.710^{-5}\left(\mathrm{~m}^{2} / \mathrm{s}\right)$. The latter calculation is indicative for the above data and it should be verified by the particular characteristics of the proposed landfill sites' locations at the examining areas and in collaboration with the Local Authorities.

However, below is proposed a sustainable solution for the waste collection on Zakynthos Island. Two waste collection transfer stations should be located next to Katastarion and Romereon locations so as to minimise waste collection costs, based on the road network and the geographical distribution among the examining Municipalities on Zakynthos Island. Several alternative solutions could be made for the waste collection routes, in collaboration with Local Authorities, taking into account particular variations of demographic elements in time and respective municipalities' needs during the peak period of holiday season, where there is big waste production. The examining costs could be minimised by the consumption of natural gas as green fuel for the waste collection vehicles (after treatment and upgrade of collected biogas) instead of oil unsustainable fuel.

\section{Conclusions}

More socioeconomic data and their trends in time should be collected in detail, especially during summer season or other holiday peak seasons, so as to determine the necessities for recycling centres' operation; particular characteristics should be taken into account for an integrated solid waste management i.e. exact location of recycled bins in relation to socioeconomic data. Also, development of sustainable sequential batch bioreactors and simulation numerical models of biomass biodegradation are useful not only to make accurate estimations of biomass emissions but also to diagnose current sites or any proposed planning scenarios. MACH's monitoring experimental data and its waste biodegradation simulation show that batch anaerobic bioreactor 
design is sustainable and its sustainable principles should be applied at any landfill site so as to be stabilised in short time. Moreover, the use of efficient diagnostic spatial analysis tools is necessary so as to take the relative right pollution confrontation measures in time. According to the above will be avoided any probable environmental pollution by long term hazardous emissions in order to protect the ecosystems and our public health.

More field data and case studies are necessary so that optimise landfill design principles. This will cause control of pollutants protecting the ecosystems, public health and exploitation of emissions helping local economy. The installation of a monitoring network next to landfill boundaries or at other selected critical locations would be useful so as to provide available data for: modelling waste input characteristics; spatial analysis of pollutants' behaviour in time for a given topography; spatial risk management; communication with the responsible Local Authorities; collect necessary data for efficient lining of proper rehabilitation works; maintenance design in time and safe control-confrontation of landfill emissions. According the above, there will be an effective protection of any surrounded ecosystems on Zakynthos Island so as to minimise any probable associated risks from the relative sources of pollution.

\section{Acknowledgements}

The authors would like to thank Dr. Louise de Rome (ETSU), U.K. Department of Trade and Industry (DTI) and U.K. Environment Agency (EA) for their support of the Mid Auchencarroch experimental project. The conclusions expressed herein represent the findings of the authors and are based on their expertise and experience in this topic area and their findings in the professional literature. It does not necessarily represent the views of EA, or of the participants in the Mid Auchencarroch Experimental Project.

\section{References}

[1] D.O.E., Waste Management Paper No 27, Landfill Gas, HMSO, UK, 1989.

[2] D.O.E., Making Waste Work, White Paper, HMSO, London, UK, 1995.

[3] D.O.E., A guide to risk assessment and risk management for environmental protection, HMSO, London, UK, 1995.

[4] Friis, R.H., Sellers, T.A., Epidemiology for Public Health Practice, Jones and Bartlett Publishers, 2004.

[5] Koliopoulos, T., Koliopoulou, G., Evaluation of Iso-Butyric Acid and Acetic Acid in landfill Leachate Emissions - Mid Auchencarroch Experimental Design, Asian Journal of Chemistry, vol. 20, (in press), 2008 .

[6] Koliopoulos, T., Koliopoulou, G., Evaluating Landfill Chemical Emissions - Mid Auchencarroch Experimental Design, Asian Journal of Chemistry, 19(5), pp. 3911-3917, 2007. 
[7] Koliopoulos, T., Koliopoulou, G., Evaluating Biomass Temperature vs Biodegradation for Environmental Impact Minimisation: Mid Auchencarroch Experimental Landfill, Asian J. Exp. Sci., 21(1), pp. 4353, 2007.

[8] Koliopoulos, T., Koliopoulou, G., Controlling Landfill Emissions for Environmental Protection: Mid Auchencarroch Experimental Project, Asian J. Exp. Sci., 20(2), pp. 233-242, 2006.

[9] Koliopoulos, T., Fleming, G., Modelling the biodegradation of treated and untreated waste and R.A. of LFG emissions - SimGasRisk, pp.625-628, Proc. of European Symposium on Environmental Biotechnology, (ESEB), ed. W. Verstraete, Taylor \& Francis, Balkema Publishers, Oostende, Belgium, 2004.

[10] KPE of Zakynthos, Information Material, Lithakias of Zakynthos, 2002.

[11] Mackenzie, D., Cornwell, D., Introduction to Environmental Engineering, McGraw Hill, USA, 1998.

[12] Turner, D.B., Workbook of Atmospheric Dispersion Estimates, HEW, Washington D.C., USA, 1969.

[13] Mpotsari, H., Operational Research, Foto Print Pubs., Athens, 1981.

[14] Museum of D. Solomos and A. Kalvos, Inform. Material, Zakynthos, 2006.

[15] Municipalities' Association of Zakynthos Island, Inform. Material, 2005.

[16] National Marine Park of Zakynthos, Inform. Material, Zakynthos, 2005.

[17] O.E.C.D, Road Safety Principles and Models: Review of Descriptive, Predictive Risk and Accident Consequence Models, Paris, 1997.

[18] O.E.C.D, Transport et Environment, Paris, 1988.

[19] Perfecture of Zakynthos, Information Material, Zakynthos, Greece, 2006.

[20] Tchobanoglous, G., Theisen, H., Vigil, S. Integrated Solid Waste Management, McGraw-Hill Book Company, New York, USA, 1993.

[21] Williams, G., Ward, R., Noy, D. Dynamics of landfill gas migration in unconsolidated sands, Waste Manage Res, 17, pp. 327-342, 1999. 